\title{
Dinamika Bisnis Selama Pandemi Covid-19 pada Tingkat Likuiditas Perusahaan Pertanian dan Consumer Goods di Indonesia
}

\author{
Arsheila Primadita $^{1}$, Nadia Asandimitra Haryono ${ }^{2}$ \\ Program Studi Manajemen, Universitas Negeri Surabaya ${ }^{1,2}$ \\ Email korespondensi: arsheilapr@gmail.com ${ }^{1}$
}

Received: 22 Mar 2021 Reviewed: 30 Mar 2021 Accepted: 8 Apr $2021 \quad$ Published: 30 Apr 2021

\begin{abstract}
The purpose of this research is to empirically prove the effect of firm size, receivable turnover, debt ratio, inventory turnover, and working capital turnover on liquidity as well as changes during the covid-19 pandemic. The object of this research is taken from the agricultural sector and consumer goods which enlisted on IDX period quarterly IV 2019, quarterly I-II 2020. This type of research is quantitative and used secondary data which consists of a quarterly financial report on IDX. The samples are obtained by using the purposive sampling method and produced 75 samples of industry. The research uses the panel data regression analysis method. Based on the result of panel data regression analysis indicated that only the debt ratio has a negative significant relation to liquidity. Firm size, receivable turnover, inventory turnover and working capital turnover aren't significant because increase or decrease in these variables do not affect the level of liquidity. During the covid-19 pandemic, there was no change in the relationship between each independent variable on liquidity.
\end{abstract}

Keywords: covid-19, debt ratio, financial performance, liquidity, operational activities

\begin{abstract}
ABSTRAK
Tujuan dari penelitian ini adalah untuk membuktikan secara empiris pengaruh ukuran perusahaan, perputaran piutang, rasio hutang, perputaran persediaan, dan perputaran modal kerja terhadap likuiditas serta perubahan selama pandemi covid-19. Objek penelitian ini diambil dari sektor pertanian dan consumer goods yang terdaftar di BEI periode triwulan IV 2019 sampai dengan triwulan I-II 2020. Jenis penelitian ini adalah kuantitatif dan menggunakan data sekunder yang terdiri dari laporan keuangan triwulanan di BEI. Pengambilan sampel dilakukan dengan menggunakan metode purposive sampling dan menghasilkan 75 sampel perusahaan. Metode yang digunakan dalam penelitian ini adalah metode analisis regresi data panel. Hasil analisis menunjukkan bahwa hanya rasio hutang yang berpengaruh signifikan negatif terhadap likuiditas. Ukuran perusahaan, perputaran piutang, perputaran persediaan dan perputaran modal kerja tidak signifikan karena kenaikan atau penurunan variabel tersebut tidak mempengaruhi tingkat likuiditas. Selama pandemi Covid-19, tidak ada perubahan hubungan antara masing-masing variabel independen terhadap likuiditas.
\end{abstract}

Kata kunci: covid-19, rasio hutang, kinerja keuangan, likuiditas, aktivitas operasional

\section{A. PENDAHULUAN}

Indonesia menjadi salah satu negara yang turut terdampak oleh paparan coronavirus disease 19 atau covid-19 pada tanggal 2 Maret 2020 dengan kasus pertamanya sebanyak 2 
orang. Deklarasi tersebut membuat lingkup domestik terguncang secara multidimensional dengan masif. Hal tersebut membuat tatanan negara mengambil sikap dan penyesuaian secara intens, khususnya pada aspek ekonomi negara dimana sebagai motor penggerak pertumbuhan nasional. Produk domestik bruto sebagai indikator utama dalam mengetahui, menilai, dan memprediksi kondisi perekonomian suatu negara pada periode waktu tertentu. Badan Pusat Statistik (2020) menjelaskan perolehan PDB hampir seluruh sektor lapangan usaha mengalami penurunan. Hal ini disebabkan oleh dampak dari adanya kebijakan pemerintah Indonesia yang menerapkan pembatasan sosial berskala besar (PSBB) yang berakibat pada penurunan daya beli masyarakat terhadap barang komoditas sehingga harga dan jumlah produksi barang dan jasa turut menurun serta adanya penerapan pembatasan aktivitas perdagangan ekspor impor. Namun, terdapat sektor usaha yang mengalami peningkatan PDB yang cukup signifikan yaitu sektor pertanian.

Sektor pertanian sebagai sektor penguat bagi ketahanan pangan nasional dalam pemulihan ekonomi karena Indonesia yang merupakan negara agraris kaya akan sumber daya alam dan mayoritas mata pencahariannya dalam lingkup tersebut. Berdasarkan data Badan Pusat Statistik (2020) perolehan PDB sektor pertanian pada Q4 2019 sebesar 449.379,30 milyar, lalu meningkat menjadi 503.727,90 milyar pada Q1 2020 dan merespon lagi secara positif menjadi 570.033,70 miliar pada Q2 2020.

Salah satu komponen utama menilai kondisi perusahaan dalam keadaan sehat atau kurang sehat yaitu dengan mengukur rasio tingkat likuiditas. Kasmir (2015) mengemukakan likuiditas memiliki fungsi sebagai suatu pengukuran kemampuan perusahaan dalam pemenuhan kewajiban finansial lancarnya baik kepada pihak internal maupun eksternal. Likuiditas bukan hanya tentang pemenuhan, tetapi juga pengelolaan aset lancar menjadi kas (Hamdi, 2014). Menurut Kasmir (2015) idealnya angka rasio yaitu 2 atau 200\%. Namun, standarisasi tiap perusahaan berbeda-beda terkait batas minimum untuk tingkat likuiditasnya.

Berdasarkan Gambar 1, rata-rata likuiditas memiliki nilai beragam. Namun, sektor yang memiliki likuiditas meningkat dan bertahan saat pandemi covid-19 adalah sektor pertanian dan consumer goods. Pada sektor pertanian, perolehan likuiditas di Q4 2019 sebesar 1,49, lalu meningkat menjadi 6,51 pada Q1 2019 dan tumbuh positif lagi menjadi 9,58 pada Q2 2020. Kementerian Pertanian Republik Indonesia (2020) menyebutkan kegiatan operasional pada sektor pertanian mengalami pertumbuhan yang positif dan kuat baik manajemen perusahaan maupun kegiatan ekspor. Subsektor yang menjadi penyumbang tertinggi PDB yaitu perkebunan khususnya tanaman pangan karena terfokuskan sebagai upaya ketahanan pangan domestik. Lanjutnya, pertumbuhan positif tersebut dipengaruhi oleh adanya peningkatan 
penjualan ekspor produk, penyederhanaan distribusi rantai pasokan dan daya serap permodalan kredit usaha rakyat (KUR).

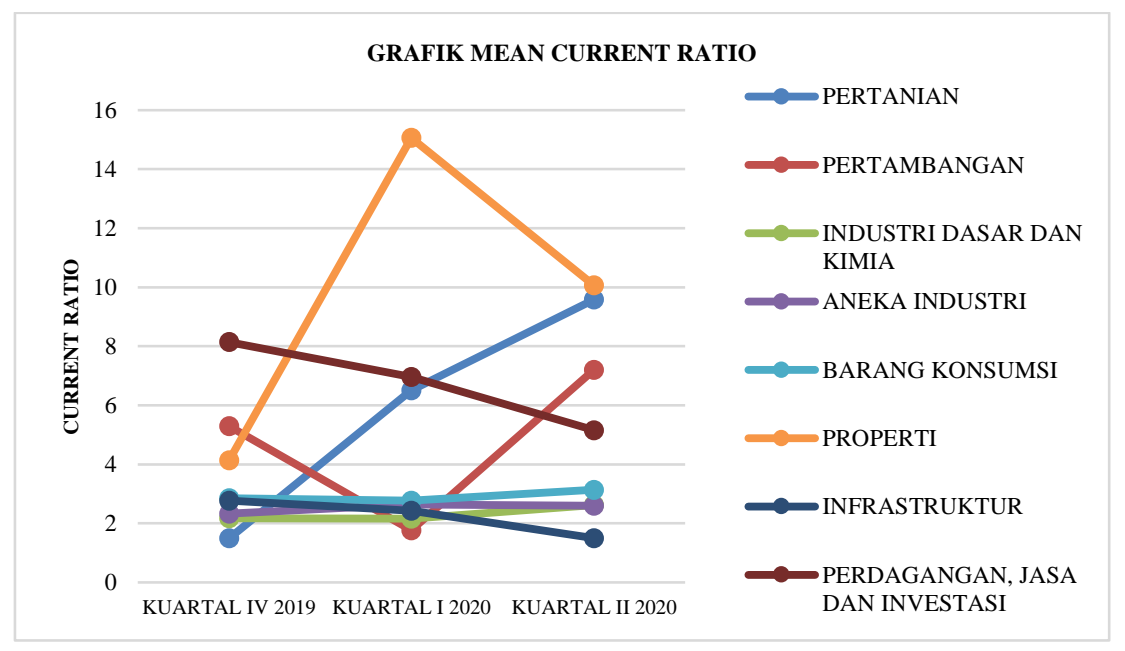

Sumber: IDX.co.id (2021, data diolah)

Gambar 1. Current Ratio Sektor Usaha Selama Pandemi Covid-19

Sektor usaha yang juga bertahan di saat pandemi covid-19 yaitu consumer goods meliputi food and beverage (F\&B), alat kesehatan, farmasi serta obat-obatan (Allianz, 2020). Diperkuat oleh Ridhoi (2020) adanya pandemi covid-19 di Indonesia hingga memasuki kuartal II 2020, industri pengolahan berkontribusi sebesar 19,87\% terhadap PDB dengan subsektor yang merespon positif yaitu consumer goods meliputi makanan dan minuman sebesar 0,22\%, kimia farmasi dan obat tradisional sebesar 8,65\%. Likuiditas yang dimiliki tidak mengalami perubahan yang signifikan seperti pada Q4 2019 perolehan likuiditasnya sebesar 2,85 lalu menurun menjadi 2,77 pada Q1 2019 dan merespon positif lagi di Q2 2020 menjadi 3,14. Di mana hal tersebut berkaitan dengan perilaku masyarakat yang sadar akan keutamaan kesehatan dan aktivitasnya untuk tetap berada di rumah.

Tingkat likuiditas dapat dipengaruhi oleh beberapa faktor baik internal maupun eksternal. Dalam penelitian ini, faktor-faktor yang digunakan adalah ukuran perusahaan, perputaran piutang, rasio hutang, perputaran persediaan, dan perputaran modal kerja. Hani (2015) menyebutkan aset lancar dan hutang lancar dapat membentuk likuiditas. Aset lancar dapat dikategorikan dalam kas, surat berharga, piutang, dan persediaan. Penelitian Kim et al. (1998) juga menambahkan ukuran perusahaan dan rasio hutang sebagai unsur yang turut memengaruhi likuiditas.

Ukuran perusahaan dapat mencerminkan seberapa makmur dalam memperoleh dan mengelola aset perusahaan. Semakin besar aset yang dimiliki maka perusahaan dinilai mandiri dan kondisi keuangan yang likuid. Pernyataan tersebut didukung Norvaišienė \& Stankevičienė 
(2014) dan Gill \& Mathur (2011) ukuran perusahaan secara positif signifikan memengaruhi likuiditas. Menurut Misnawati (2019) memengaruhi secara negatif signifikan. Berbeda dengan Puspitasari \& Haryanto (2013) dan Sugiono \& Christiawan (2013) yang tidak memengaruhi secara signifikan terhadap likuiditas.

Faktor selanjutnya yaitu perputaran piutang di mana sebagai investasi manajemen perusahaan yang tertanam pada piutang yang tertagih dan dikonversikan ke dalam kas sehingga dapat meningkatkan likuiditas. Penelitian Puspitasari \& Haryanto (2013), Ammy \& Alpi (2018), Indarti \& Oetomo (2019), (Aji et al. (2016), Ningsih \& Soekotjo (2018), Astuti \& Maelona (2013) dan Savitri \& Dianingsih (2015) menyebutkan perputaran piutang secara positif signifikan memengaruhi likuiditas. Di sisi lain, Chakiki (2016) dan Dewi (2016) memengaruhi secara negatif signifikan. Berbeda dengan Maulana (2011), Gaol (2015) dan Aminah \& Hidayat (2014) yang tidak memengaruhi secara signifikan terhadap likuiditas.

Rasio hutang sebagai pengukuran penggunaan dana eksternal untuk mendanai kekayaan perusahaan dengan tujuan mendorong kegiatan operasionalnya agar sustainable dan memperoleh laba. Penelitian Bem et al. (2014), Misnawati (2019), dan Maulana (2011) menunjukkan hasil negatif signifikan terhadap likuiditas. Penggunaan hutang yang tinggi dengan nilai aset yang tetap maka akan sulit membayar nominal hutangnya ditambah adanya beban bunga sehingga dapat mengurangi likuiditas. Berbeda dengan Puspitasari \& Haryanto (2013) yang tidak memengaruhi secara signifikan terhadap likuiditas

Selanjutnya, perputaran persediaan merupakan faktor utama investasi manajemen perusahaan yang ditanamkan pada barang persediaan dan dikonversikan ke dalam kas sehingga mendapatkan laba dan sekaligus meningkatkan likuiditas. Hasil penelitian Pranaditya (2018), Yunita \& Argamaya (2017) dan Aji et al. (2016) menyebutkan perputaran persediaan secara positif signifikan memengaruhi likuiditas. Di sisi lain, Dewi (2016) mengemukakan memengaruhi secara negatif signifikan. Bertolak belakang dengan lainnya, Gaol (2015) dan Mulyanti \& Supriyani (2018) yang tidak memengaruhi secara signifikan terhadap likuiditas.

Faktor terakhir yaitu perputaran modal kerja yang merupakan hasil keseluruhan dari kegiatan operasional yang dijalankan dan kemudian dikelola agar memperoleh modal kembali untuk meningkatkan likuiditas perusahaan. Tingkat efektivitas perusahaan dalam mengelola modal kerjanya menentukan keberlangsungan kegiatan operasionalnya. Penelitian Sugiono \& Christiawan (2013) menyebutkan perputaran modal kerja secara positif signifikan memengaruhi likuiditas. Di sisi lain, Pranaditya (2018), Saputra et al. (2020), Misnawati (2019), Chakiki (2016), Indarti \& Oetomo (2019), Ningsih \& Soekotjo (2018), Heriyanto \& Herliana (2016) dan Yunita \& Argamaya (2017) mengemukakan modal kerja secara negatif 
signifikan memengaruhi likuiditas. Pengeluaran untuk modal kerja yang tinggi menyebabkan adanya pengurangan kas sehingga likuiditas juga turut menurun. Bertolak belakang dengan Ammy \& Alpi (2018), Savitri (2014), Aji et al. (2016), Dewi (2016), Maulana (2011), Savitri \& Dianingsih (2015) dan Julita (2015) yang menyatakan bahwa modal kerja tidak memiliki pengaruh terhadap likuiditas.

Oleh karena itu, penelitian ini dilakukan untuk mengetahui dan menganalisis pengaruh ukuran perusahaan, perputaran piutang, rasio hutang, perputaran persediaan, dan perputaran modal kerja terhadap likuiditas pada industri sektor pertanian dan consumer goods di Indonesia yang terdaftar di Bursa Efek Indonesia selama pandemi covid-19. Selain itu, juga mengetahui perubahan terkait hubungan antar variabel independen tersebut terhadap likuiditas selama pandemi covid-19.

\section{B. TELAAH PUSTAKA}

\section{Pecking Order Theory}

Menurut Myers (1984) pecking order theory menjelaskan secara hierarki terkait pemilihan sumber pendanaan yang dipilih suatu perusahaan. Sudana (2011) mengemukakan perusahaan dengan penghasil laba tertinggi dinilai mampu memperoleh kas internal yang optimal untuk kebutuhan operasional dan investasi sehingga penggunaan dana eksternal rendah atau menghapus biaya hutang. Sebaliknya, jika perusahaan menghasilkan laba rendah karena tidak mampu mencukupi kebutuhan operasionalnya maka cenderung menggunakan dana eksternal dan atau lebih menyukai kebijakan pendanaan eksternal (Husnan \& Pudjiastuti, 2012). Teori ini berhubungan dengan ukuran perusahaan dan rasio hutang sesuai dengan Kim et al. (1998) apabila ukuran perusahaan tinggi mencerminkan perusahaan berada di titik kemandirian dalam menghasilkan laba sehingga penggunaan dana internal lebih utama daripada dana eksternal dalam kegiatan operasional maupun investasi. Maka, pecking order theory digunakan untuk menjelaskan keterkaitan ukuran perusahaan dan rasio hutang yang mampu memengaruhi likuiditas.

\section{Liquidity Preference Theory}

Keynes (1936) mengemukakan liquidity preference theory berkaitan dengan penentuan tingkat suku bunga terhadap permintaan uang di mana diklaim sebagai tingkat likuiditas. Konsep tersebut bermakna sebagai perolehan pendapatan dan diwujudkan dalam bentuk uang tunai atau kas. Teori ini berhubungan dengan perputaran piutang dan perputaran persediaan jika semakin tinggi perputaran piutang dan perputaran persediaan maka pendapatan yang diperoleh semakin cepat yang dikonversikan dalam bentuk kas. Maka, liquidity preference 
theory digunakan untuk menjelaskan keterkaitan perputaran piutang dan perputaran persediaan yang mampu memengaruhi likuiditas.

\section{Signaling Theory}

Investor/kreditor dalam menilai dan mempertimbangkan citra perusahaan serta pengelolaan manajemen untuk kegiatan penanaman modal atau investasi dengan melihat informasi seperti laporan keuangan yang berisi prospek yang menguntungkan di masa yang akan datang atau tidak (Brigham \& Houston, 2014). Menurut Fahmi (2011), laporan keuangan menggambarkan kinerja keuangan perusahaan dan sebagai fundamental perusahaan dalam pengambilan keputusan serta kebijakan seperti investasi. Sinyal yang berisi informasi dari laporan keuangan tersebut dapat direspon positif maupun negatif oleh investor/kreditor. Sinyal positif dapat ditunjukkan dengan adanya peningkatan laba perusahaan dan prospek yang tinggi di masa yang akan datang sehingga investor/kreditor tertarik untuk transaksi dan menanamkan modalnya yang berdampak pada citra perusahaan. Teori ini berhubungan dengan perputaran modal kerja apabila semakin tinggi perputaran modal kerja maka perusahaan dinilai efektif dalam pengelolaan modal kerja untuk memperoleh laba sehingga memberikan sinyal positif bagi investor/kreditor untuk melakukan penanaman modal dengan prospek yang menguntungkan juga di masa yang akan datang. Oleh karena itu, signaling theory digunakan untuk menjelaskan keterkaitan perputaran modal kerja yang mampu memengaruhi likuiditas.

\section{Likuiditas}

Seligova (2017) berpendapat likuiditas merupakan indikator penting sebagai pengukuran untuk mengetahui kemampuan perusahaan dalam memenuhi kewajiban finansial lancarnya tanpa menyebabkan kerugian di luar yang diharapkan dan likuiditas memiliki periode waktu berjalan selama satu tahun pembukuan perusahaan. Likuiditas dapat diukur menggunakan current ratio dengan perbandingan antara total aset lancar yang dimiliki dengan hutang lancarnya untuk menilai harapan dari investor/kreditor terkait jangka pendeknya yang dipenuhi oleh aset (Kasmir, 2015). Kasmir (2015) menilai current ratio dapat diformulasikan dengan rumus:

$$
\text { Current Ratio }=\frac{\text { Aset lancar }}{\text { Utang lancar }}
$$

\section{Ukuran Perusahaan}

Skala atau ukuran perusahaan suatu gambaran atas pengelompokkan tingkatan perusahaan yang ditinjau dari kekayaan yang dimiliki atau lapangan usaha yang dijalankan dan ditentukan atas dasar total penjualan, total aset dan rata-rata penjualan (Seftianne \& Handayani, 
2011). Sawir (2004) menjelaskan perusahaan dengan kekayaan atau lapangan usaha yang besar cenderung memperoleh keuntungan lebih banyak dibandingkan dengan perusahaan yang berskala kecil. Menurut Jogiyanto (2000) untuk mengetahui posisi tingkatan perusahaan dapat diformulasikan dengan rumus:

\section{Ukuran Perusahaan $=$ Ln Total Aset}

\section{Perputaran Piutang}

Piutang usaha merupakan perolehan hasil perusahaan yang timbul akibat adanya penjualan barang dan jasa secara kredit. Sunyoto (2013) menjelaskan penjualan secara kredit dapat diterapkan secara keseluruhan atau sebagian saja dan nilai dari penjualan tersebut mampu memberikan dampak pada tingkat perputaran piutang. Menurut Kasmir (2015) perputaran piutang digunakan sebagai alat ukur waktu penagihan piutang pada periode piutang berjalan. Kasmir (2012) menjelaskan perputaran piutang dapat diformulasikan dengan rumus:

$$
R T O=\frac{\text { Penjualan Bersih }}{\text { Rata }- \text { rata piutang }}
$$

\section{Rasio Hutang}

Hutang sebagai salah satu sumber pendanaan eksternal perusahaan. Keown et al. (2008) mengemukakan penggunaan dana eksternal dilakukan jika adanya pendapatan dan ketersediaan nilai aset yang disesuaikan atas kesepakatan antara kreditor dan debitur sebagai penentu jaminan dan analisis risiko yang telah diasumsikan. Rasio hutang memberikan gambaran terkait proporsi jumlah nominal dana eksternal yang digunakan untuk membiayai aset keseluruhan perusahaan (Keown et al., 2008). Menurut Kasmir (2012) rasio hutang dapat diformulasikan dengan rumus:

$$
D T A=\frac{\text { Total Utang }}{\text { Total Aset }}
$$

\section{Perputaran Persediaan}

Menurut Rudianto (2009) persediaan terdiri atas bahan baku, barang dalam proses, dan barang jadi yang dimiliki perusahaan dengan tujuan untuk diproses dengan solid dan dijual untuk mendapatkan laba dengan menanamkan nilai modal atau investasi di dalamnya. Perputaran persediaan sebagai pengukuran tingkat efektivitas nilai investasi atau modal yang ditanam pada persediaan dengan perolehan tingkat pengembalian yang dikonversikan dalam bentuk kas pada periode waktu tertentu (Moeljadi, 2006). Menurut Kasmir (2012) perputaran persediaan dapat diformulasikan dengan rumus:

$$
\text { ITO }=\frac{\text { Harga Pokok Penjualan }}{\text { Persediaan }}
$$




\section{Perputaran Modal Kerja}

Modal kerja sebagai aset utama untuk keberlangsungan kegiatan operasional perusahaan. Munawir (2010) mengemukakan perputaran modal kerja sebagai pengukuran tingkat efektivitas modal kerja perusahaan dalam satu periode seberapa besar tingkat pengembalian jumlah modal kerja yang dimiliki yang telah diinvestasikan pada satu periode berjalan. Perputaran modal kerja memiliki hubungan antara modal kerja dengan tingkat penjualan yang didapatkan perusahaan untuk setiap jumlah nilai modal kerjanya (Munawir, 2007). Menurut Kasmir (2012) perputaran modal kerja dapat diformulasikan dengan rumus:

$$
N W C T=\frac{\text { Penjualan Bersih }}{\text { Modal Kerja Bersih }}
$$

\section{Hubungan Antar Variabel}

Menurut Jogiyanto (2000), ukuran perusahaan dapat ditinjau dari total kekayaan aset yang dimiliki dan sebagai salah satu indikator yang turut andil dalam keberlanjutan manajemen perusahaan serta mencerminkan kinerja dari kegiatan operasional maupun investasi yang dijalankan. Besar kecilnya tingkatan perusahaan diukur dengan logaritma dari perolehan keseluruhan aset perusahaan. Secara jelas, dari total aset tersebut mencerminkan kinerja dari kegiatan operasional maupun investasi yang dijalankan. Semakin besar perusahaan maka mampu menguasai persaingan atau bertahan dalam industri (Sugiono \& Christiawan, 2015). Gill \& Mathur (2011) menyebutkan semakin besar sebuah perusahaan maka aset yang dimiliki semakin likuid sehingga berada dalam posisi terbaik untuk mendanai kegiatan operasional yang tidak likuid dengan meningkatkan modal di pasar modal untuk mencapai titik kemandirian.

Pernyataan tersebut didukung oleh pecking order theory bahwa perusahaan dengan perolehan laba tinggi mampu menghasilkan kas internal yang optimal untuk kebutuhan operasional sehingga lebih mengutamakan penggunaan dana internal daripada eksternal. Menurut teori tersebut ukuran perusahaan memiliki pengaruh terhadap likuiditas. Teori tersebut didukung penelitian Gill \& Mathur (2011) dan Norvaišienė \& Stankevičienė (2014). Ukuran perusahaan memiliki pengaruh secara positif dan signifikan terhadap likuiditas. Semakin besar kekayaan aset perusahaan maka perolehan laba juga turut tinggi dan perusahaan memiliki cadangan kas internal dengan optimal sehingga tingkat likuiditas perusahaan dalam kondisi likuid. Menurut Misnawati (2019) ukuran perusahaan berpengaruh negatif signifikan terhadap likuiditas. Artinya, semakin besar kekayaan asetnya maka tingkat likuiditas menurun dikarenakan kegiatan operasional yang meningkat dan kompleks membutuhkan modal kerja yang tinggi juga serta perusahaan yang besar mudah dalam mendapatkan pendanaan eksternal sehingga tingkat likuiditas cenderung rendah. Di sisi lain, Sugiono \& Christiawan (2013) dan 
Puspitasari \& Haryanto (2013) menyebutkan ukuran perusahaan tidak memiliki pengaruh yang signifikan terhadap likuiditas.

$\mathrm{H}_{1}$ : Ukuran perusahaan berpengaruh terhadap likuiditas pada industri sektor pertanian dan consumer goods yang terdaftar di Bursa Efek Indonesia periode Q4 2019, Q1-Q2 2020

Perputaran piutang sebagai faktor penting untuk mengetahui tingkat efisiensi kualitas nilai modal yang tertanam dalam piutang hingga tertagih. Menurut Keown et al. (2008) perputaran piutang menunjukkan periode waktu penagihan dengan kurun waktu nilai piutang selama periode berjalan. Perputaran piutang dapat diukur melalui penjualan kredit bersih yang dilakukan bersama dengan rata-rata piutang yang didapatkan. Penjualan kredit sebagai salah satu investasi perusahaan dalam bentuk piutang untuk mendapatkan pendapatan internal. Semakin cepat perputaran piutang maka nilai yang ditanam pada piutang rendah dan mencerminkan kualitas piutang yang optimal serta semakin cepat modal kembali untuk mencapai likuid (Prihadi, 2010). Dalam hal ini, piutang yang tertagih dapat dikonversikan dalam bentuk kas sehingga perolehan kas internal juga turut bertambah dan secara mandiri telah mampu mengelola segala kegiatan operasionalnya dengan menggunakan dana internal.

Pernyataan tersebut didukung oleh liquidity preference theory yang menyatakan perolehan pendapatan yang didapatkan dapat diwujudkan dalam bentuk uang tunai atau kas. Kas tersebut dapat menghindarkan perusahaan dari pendanaan eksternal yang akan menambah beban kembali. Menurut teori tersebut perputaran piutang memiliki pengaruh terhadap likuiditas. Teori tersebut didukung Puspitasari \& Haryanto (2013), Ammy \& Alpi (2018), Indarti \& Oetomo (2019), Aji et al. (2016), Ningsih \& Soekotjo (2018), Astuti \& Maelona (2013) dan Savitri \& Dianingsih (2015) perputaran piutang memiliki pengaruh secara positif dan signifikan terhadap likuiditas. Semakin tinggi tingkat perputaran piutang maka pencapaian efektif dan efisien perusahaan dalam pengelolaan piutang yang tertagih semakin optimal untuk diubah menjadi kas dan modal kerja perusahaan yang diinvestasikan dalam piutang cepat kembali. Menurut Chakiki (2016) dan Dewi (2016) perputaran piutang memiliki pengaruh secara negatif signifikan terhadap likuiditas. Artinya, perputaran piutang yang tinggi. Namun, rata-rata nilai piutang yang diperoleh rendah maka jumlah piutang yang tertagih juga turut rendah sehingga nilai investasi yang tertanam dalam piutang tidak optimal untuk dikonversikan ke dalam kas dan likuiditas menjadi rendah. Di sisi lain, Maulana (2011), Gaol (2015), dan Aminah \& Hidayat (2014) menjelaskan perputaran piutang tidak memiliki pengaruh yang signifikan terhadap likuiditas.

$\mathrm{H}_{2}$ : Perputaran piutang berpengaruh terhadap likuiditas pada industri sektor pertanian dan consumer goods yang terdaftar di Bursa Efek Indonesia periode Q4 2019, Q1-Q2 2020 
Rasio hutang sebagai proporsi penggunaan pendanaan eksternal perusahaan dengan ketersediaan aset perusahaan untuk mendanai keseluruhan aset yang digunakan untuk kegiatan operasional maupun investasi. Menurut Kasmir (2012) rasio hutang dapat diukur dengan perbandingan perolehan total aset dengan total hutang. Hutang secara umum bagian dari komitmen perusahaan dalam jangka pendek yang berkaitan dengan kegiatan operasi tidak untuk berinvestasi (Bem et al., 2014). Misnawati (2019) menyebutkan semakin tinggi rasio hutang maka semakin besar risiko yang dihadapi berkaitan dengan kegiatan operasional sehingga likuiditas menjadi tidak stabil.

Menurut pecking order theory, perusahaan dalam menghasilkan laba tinggi cenderung menggunakan dana eksternal yang rendah dan secara hierarki mengutamakan dana eksternal. Maka, teori tersebut dapat menjelaskan rasio hutang berpengaruh terhadap likuiditas. Teori tersebut didukung Maulana (2011), Misnawati (2019), dan Bem et al. (2014) rasio hutang memiliki pengaruh secara negatif signifikan terhadap likuiditas. Semakin tinggi rasio hutang maka biaya-biaya yang timbul atas pendanaan eksternal untuk aset perusahaan mengharuskan untuk mengeluarkan cadangan kas yang lebih untuk memenuhinya dengan nilai aset perusahaan yang tetap sehingga likuiditas semakin menurun. Menurut Puspitasari \& Haryanto (2013) rasio hutang tidak memiliki pengaruh yang signifikan terhadap likuiditas.

$\mathrm{H}_{3}$ : Rasio hutang berpengaruh terhadap likuiditas pada industri sektor pertanian dan consumer goods yang terdaftar di Bursa Efek Indonesia periode Q4 2019, Q1-Q2 2020

Harjito \& Martono (2008) mengemukakan perputaran persediaan memberikan gambaran terkait pergerakan persediaan yang digunakan baik masuk atau keluar dan digantikan kembali dengan baru untuk mencapai efektif dan efisien. Pergerakan tersebut diukur oleh harga pokok penjualan produk dengan rata-rata persediaan yang digunakan. Menurut Yunita \& Argamaya (2017) semakin tinggi perputaran persediaan maka persediaan yang terjual banyak dan risiko potensi kerugian atas deflasi atau pergeseran trend juga rendah sehingga perusahaan tetap dalam kondisi likuid. Peningkatan penjualan produk berdasarkan tingginya nilai persediaan akan memperoleh pendapatan tinggi dalam bentuk kas yang nantinya digunakan untuk memenuhi kewajiban finansial lancarnya.

Pernyataan tersebut didukung oleh liquidity preference theory di mana perolehan pendapatan atas penjualan dapat diwujudkan dalam bentuk uang tunai atau kas. Menurut teori tersebut perputaran persediaan memiliki pengaruh terhadap likuiditas. Teori tersebut didukung Pranaditya (2018), Aji et al. (2016), dan Yunita \& Argamaya (2017) yang menyatakan perputaran persediaan memiliki pengaruh positif dan signifikan terhadap likuiditas. Semakin tinggi perputaran persediaan maka semakin cepat persediaan yang dikelola baik barang masuk 
dan keluar dikarenakan aktivitas penjualan produk meningkat sehingga perolehan laba atas setiap nilai investasi yang tertanam dalam persediaan dapat cepat dikonversikan ke dalam kas internal. Menurut Dewi (2016), perputaran piutang memiliki pengaruh secara negatif signifikan terhadap likuiditas. Artinya, perputaran persediaan tinggi namun aktivitas penjualan produk atas barang persediaan melambat atau stagnan maka proses produksi juga melambat dikarenakan barang persediaan yang digunakan telah diproduksi sehingga risiko untuk hutang terhadap pembelian barang persediaan kembali tinggi maka likuiditas turut menurun disebabkan adanya biaya tambahan atas hutang pembelian. Di sisi lain, Gaol (2015) dan Mulyanti \& Supriyani (2018) menjelaskan perputaran persediaan tidak memiliki pengaruh yang signifikan terhadap likuiditas.

$\mathrm{H}_{4}$ : Perputaran persediaan berpengaruh terhadap likuiditas pada industri sektor pertanian dan consumer goods yang terdaftar di Bursa Efek Indonesia periode Q4 2019, Q1-Q2 2020

Kasmir (2012) mengemukakan perputaran modal kerja dapat diukur oleh penjualan dan selisih antara kekayaan dengan pendanaan agar memperoleh laba setiap yang ditanamkan untuk mencapai efektivitas. Perputaran modal kerja berjalan ketika aset lancar telah diinvestasikan ke dalam elemen modal kerja hingga kembali lagi (Yunita \& Argamaya, 2017). Semakin tinggi perputaran modal kerja mencerminkan perolehan penjualan bersih perusahaan meningkat maka laba yang diperoleh juga tinggi dan pengelolaan akan investasi pada modal kerja lebih mudah dilakukan sehingga dengan cepat modal kembali dan aset lancar tersedia sehingga perusahaan dalam kondisi likuid untuk mengelola kegiatan operasionalnya.

Pernyataan tersebut didukung oleh signaling theory yang menyebutkan tingkat profitabilitas yang tinggi menunjukkan prospek atau citra perusahaan berada dititik kemandirian dan kedewasaan sehingga pihak eksternal akan memberikan sinyal atau respon kepada internal perusahaan. Hal ini akan berdampak pada peningkatan penjualan sehingga menurut teori tersebut perputaran modal kerja memiliki pengaruh terhadap likuiditas. Teori tersebut didukung Sugiono \& Christiawan (2013) perputaran modal kerja memiliki pengaruh secara positif dan signifikan terhadap likuiditas. Semakin tinggi perputaran modal kerja maka perolehan nilai atas setiap modal kerja yang ditanam semakin cepat kembali dalam bentuk aset lancar atau kas sehingga cadangan kas internal meningkat.

Menurut Heriyanto \& Herliana (2016), Pranaditya (2018), Saputra et al. (2020), Misnawati (2019), Chakiki (2016), Indarti \& Oetomo (2019), Ningsih \& Soekotjo (2018), dan Yunita \& Argamaya (2017) perputaran modal kerja memiliki pengaruh negatif signifikan terhadap likuiditas. Artinya, semakin tinggi perputaran modal kerja maka semakin banyak modal kerja atau aset lancar yang dikeluarkan untuk dikelola dalam kegiatan operasional 
maupun investasi sehingga cadangan kas internal berkurang dan likuiditas rendah. Di sisi lain, Ammy \& Alpi (2018), Savitri (2014), Aji et al. (2016), Dewi (2016), Maulana (2011), Savitri \& Dianingsih (2015) dan Julita (2015) menjelaskan perputaran modal kerja tidak memiliki pengaruh yang signifikan terhadap likuiditas.

$\mathrm{H}_{5}$ : Perputaran modal kerja berpengaruh terhadap likuiditas pada industri sektor pertanian dan consumer goods yang terdaftar di Bursa Efek Indonesia periode Q4 2019, Q1-Q2 2020.

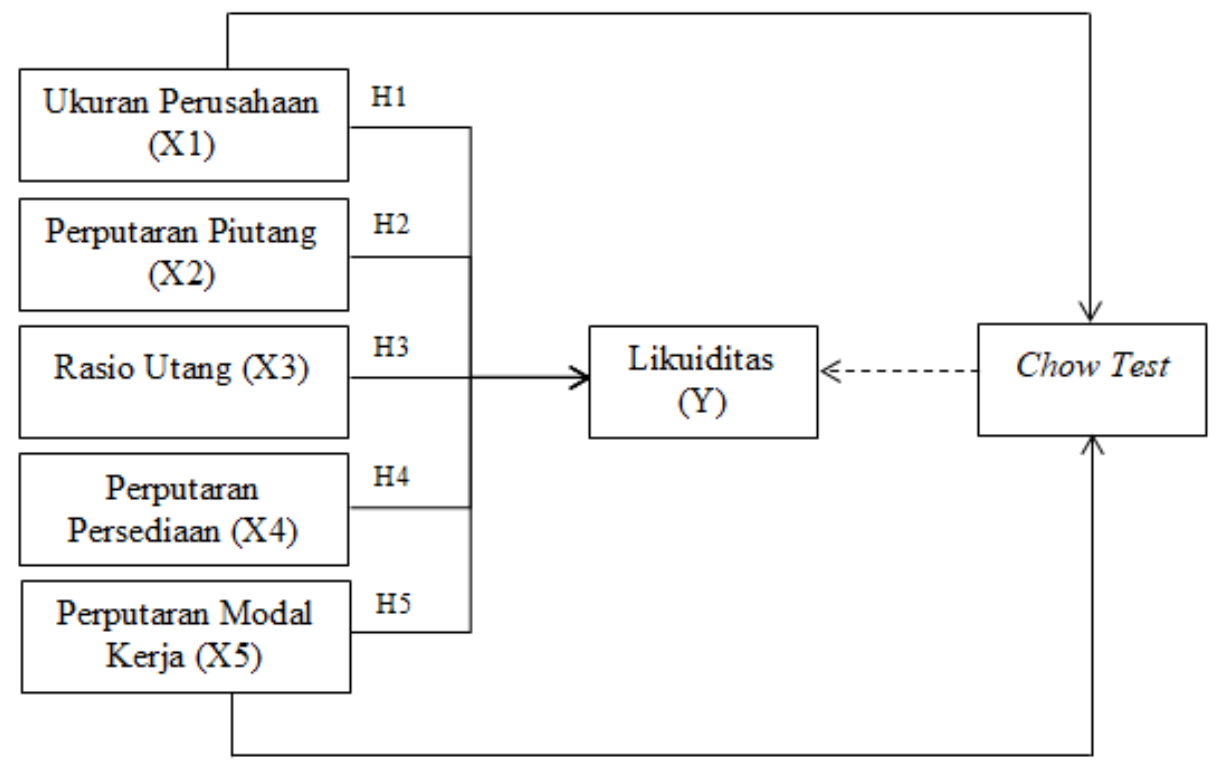

Sumber: Data diolah penulis (2021)

Gambar 2. Model Penelitian

\section{METODE PENELITIAN}

Jenis penelitian yang diterapkan yaitu pendekatan asosiatif kausalitas untuk membuktikan adanya hubungan sebab akibat antara variabel-variabel independen terhadap likuiditas. Penelitian menggunakan jenis data kuantitatif dan data tersebut berupa data sekunder yang diperoleh dari laman resmi Bursa Efek Indonesia (BEI) dan laman resmi tiap-tiap perusahaan terkait yang menjadi objek pada penelitian. Populasi dalam penelitian ini yaitu industri sektor pertanian dan consumer goods yang terdaftar di Bursa Efek Indonesia (BEI) periode kuartal IV tahun 2019, kuartal I-II tahun 2020.

Teknik penentuan sampel menggunakan metode purposive sampling dengan kriteria industri/perusahaan yang terdaftar di Bursa Efek Indonesia (BEI) dan mempublikasikan laporan keuangan secara berturut-turut periode kuartal IV tahun 2019, kuartal I-II tahun 2020 serta tidak delisting. Maka, diperoleh sebesar 75 perusahaan yang memenuhi kriteria sampel. Teknik analisis data yang digunakan yaitu analisis regresi data panel melalui beberapa tahapan 
uji seperti uji chow dan uji hausman. Selanjutnya, dilakukan uji asumsi klasik meliputi uji normalitas, uji heteroskedastisitas, uji multikolinieritas. Tahap akhir yaitu uji hipotesis seperti uji kelayakan model (statistik F), uji statistik t, koefisien determinasi $\left(R^{2}\right)$.

\section{HASIL DAN PEMBAHASAN}

Dalam regresi data panel terdapat uji estimasi model untuk mencari model yang tepat untuk digunakan. Pertama, dilakukan uji chow sebagai penentuan model terbaik antara common effect model (CEM) dan fixed effect model (FEM). Hasil dari uji chow menunjukkan nilai probabilitas Chi-square sebesar 0,0000 atau < 0,05, maka model yang tepat digunakan adalah fixed effect model (FEM). Selanjutnya, dilakukan uji hausman sebagai penentuan model terbaik antara fixed effect model (FEM) dan random effect model (REM). Hasil dari uji hausman menunjukkan nilai probabilitas cross-section random sebesar 0,0393 atau < 0,05, maka model yang tepat digunakan adalah fixed effect model (FEM). Output regresi data panel dengan menggunakan fixed effect model (FEM) dapat diformulasikan dalam persamaan regresi sebagai berikut:

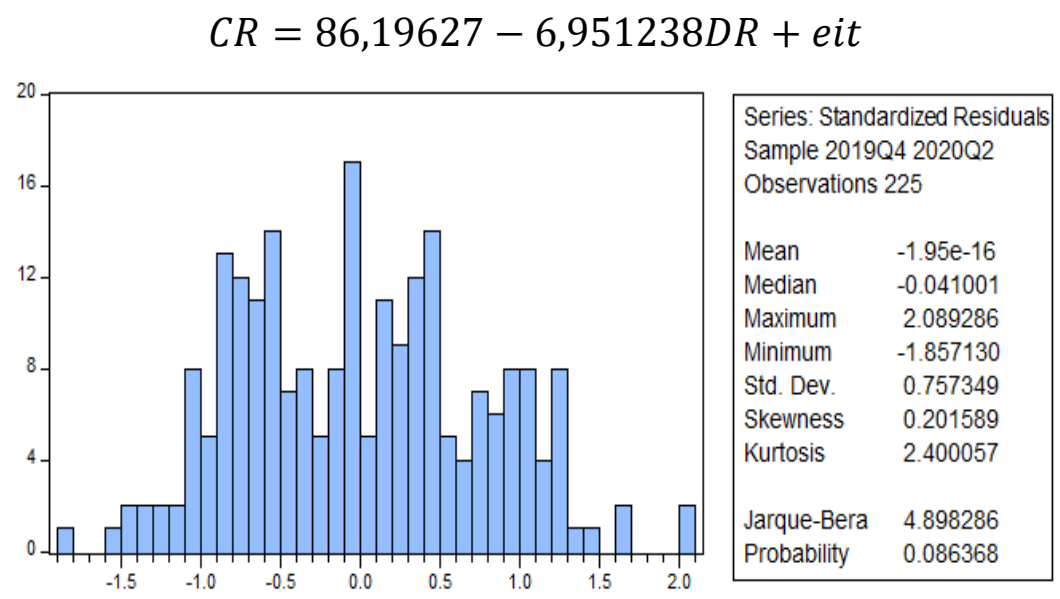

Sumber: Output Eviews 10 (2021)

Gambar 3. Histogram Uji Normalitas

Untuk mengetahui persamaan regresi yang digunakan telah terdistribusi normal atau tidak dapat dilakukan uji normalitas terlebih dahulu yang ditinjau dari nilai variabel residual. Berdasarkan Gambar 3, hasil uji normalitas dilihat pada nilai probabilitas Jarque-Bera yaitu sebesar 0,086368 atau > 0,05, maka dapat dikatakan data telah terdistribusi secara normal.

Selanjutnya, untuk menguji indikasi adanya korelasi atau hubungan yang kuat antar variabel independen atau tidak dilakukan uji multikolinieritas. Hasil uji multikolinieritas menunjukkan rentang perolehan nilai terendah sebesar -0,055309 hingga tertinggi sebesar 0,483163 atau $\leq 0,95$, maka dapat dikatakan tidak terjadi korelasi atau terbebas dari gejala multikolinieritas. Terakhir, dilakukan uji heteroskedastisitas untuk mengetahui penyimpangan 
varians nilai residual dari persamaan regresi yang digunakan antar pengamatan. Uji ini menggunakan uji glejser dengan rentang perolehan nilai probabilitas terendah sebesar 0,2347 hingga tertinggi sebesar 0,9152 atau >0,05, maka dapat dikatakan data terbebas dari gejala heteroskedastisitas.

Tabel 1. Fixed Effect Model (FEM)

\begin{tabular}{cccccc}
\hline Variabel & Coefficient & Std. Error & t-Statistic & Probabilitas & Prob(F-Statistic) \\
\hline & & & & & 0,000000 \\
C & 86,19627 & 44,38686 & 1,941932 & 0,0541 & \\
X1 & $-2,808685$ & 1,554164 & $-1,807200$ & 0,0728 & \\
X2 & $-0,000402$ & 0,008729 & $-0,046081$ & 0,9633 & \\
X3 & $-6,951238$ & 2,360441 & $-2,944889$ & 0,0038 & \\
X4 & $-0,007779$ & 0,023747 & $-0,327592$ & 0,7437 & \\
X5 & $-0,002805$ & 0,009374 & $-0,299274$ & 0,7652 & \\
\hline
\end{tabular}

Sumber: Output Eviews 10 (2021, data diolah)

Berdasarkan Tabel 1, hasil uji F dengan nilai probabilitas sebesar 0,000000 atau < 0,05, artinya variabel ukuran perusahaan, perputaran piutang, rasio hutang, perputaran persediaan, dan perputaran modal kerja mampu menjelaskan adanya hubungan terhadap likuiditas. Selanjutnya, hasil uji $\mathrm{t}$ menunjukkan nilai $\mathrm{t}$ hitung $\mathrm{X}_{1}$ sebesar $-1,807200$ dengan nilai probabilitas 0,0728 atau > 0,05, maka Ha ditolak dan $\mathrm{H}_{0}$ diterima. Artinya, ukuran perusahaan tidak memengaruhi likuiditas perusahaan. Pada $\mathrm{X}_{2}$, nilai t hitung diperoleh sebesar $-0,046081$ dengan nilai probabilitas 0,9633 atau > 0,05, maka $\mathrm{Ha}$ ditolak dan $\mathrm{H}_{0}$ diterima. Artinya, perputaran piutang tidak memengaruhi likuiditas perusahaan. Pada $\mathrm{X}_{3}$, nilai $\mathrm{t}$ hitung diperoleh sebesar -2,944889 dengan nilai probabilitas 0,0038 atau < 0,05, maka $\mathrm{H}_{0}$ ditolak dan $\mathrm{Ha}$ diterima. Artinya, rasio hutang memengaruhi likuiditas perusahaan dengan arah negatif. Pada $\mathrm{X} 4$, nilai t hitung diperoleh sebesar $-0,327592$ dengan nilai probabilitas 0,7437 atau $>0,05$, maka $\mathrm{Ha}$ ditolak dan $\mathrm{H}_{0}$ diterima. Artinya, perputaran persediaan tidak memengaruhi likuiditas perusahaan. Terakhir, pada $X_{5}$, nilai t hitung diperoleh sebesar -0,299274 dengan nilai probabilitas 0,7652 atau > 0,05, maka Ha ditolak dan $\mathrm{H}_{0}$ diterima. Artinya, perputaran modal kerja tidak memengaruhi likuiditas perusahaan.

Hasil uji koefisien determinasi pada penelitian diperoleh nilai Adjusted $R$ Square sebesar 0,847945 atau $84,7945 \%$. Hal ini dapat dikatakan kemampuan persamaan model pada variabel independen yaitu ukuran perusahaan, perputaran piutang, rasio hutang, perputaran persediaan dan perputaran modal kerja mampu menjelaskan tingkat variasi dependen sebesar 84,7945\%. Sementara selisihnya 15,2055\% dipengaruhi atau dijelaskan oleh variabel lain di luar model seperti pertumbuhan penjualan dan laba perusahaan. 
Selanjutnya, dilakukan chow test untuk mengetahui kesamaan koefisien persamaan regresi pada keseluruhan pengamatan. Hasil pengamatan diklasifikasikan menjadi 2 kondisi yaitu sebelum deklarasi covid-19 di Indonesia dan sesudah deklarasi covid-19 di Indonesia untuk melihat adanya perubahan terkait hubungan tiap variabel independen yaitu ukuran perusahaan, perputaran piutang, rasio utang, perputaran persediaan dan perputaran modal kerja terhadap likuiditas selama pandemi covid-19.

Berdasarkan Tabel 2, hasil nilai residual dari tiap variabel independen. Pada $\mathrm{X}_{1}$ diperoleh nilai $\mathrm{F}$ hitung sebesar 0,1865 dan $\mathrm{F}$ tabel 3,036710 atau $\mathrm{F}$ hitung $<\mathrm{F}$ tabel dengan $\mathrm{df}=2$ dan $\mathrm{n}$ $=221$ serta signifikansi 0,05. Artinya, tidak terdapat perubahan hubungan antara ukuran perusahaan terhadap likuiditas selama pandemi covid-19.

Tabel 2. Nilai Restricted Sum Squared Residual (RSSr)

\begin{tabular}{cccc}
\hline Variabel & $\begin{array}{c}\text { Keseluruhan } \\
\text { pengamatan } \\
(\mathbf{Q 4 ~ 2 0 1 9}-\mathbf{Q 2} \text { 2020 })\end{array}$ & $\begin{array}{c}\text { Sebelum deklarasi } \\
\text { covid-19 di Indonesia } \\
(\mathbf{Q 4} \text { 2019) }\end{array}$ & $\begin{array}{c}\text { Sesudah deklarasi } \\
\text { covid-19 di Indonesia } \\
\text { (Q1-Q2 2020) }\end{array}$ \\
\hline X1 & 1657,291 & 386,9030 & 1267,596 \\
X2 & 1623,887 & 370,9034 & 1250,686 \\
X3 & 1268,735 & 302,7027 & 956,1457 \\
X4 & 1614,556 & 363,7570 & 1235,794 \\
X5 & 1645,489 & 372,0663 & 1272,982 \\
\hline
\end{tabular}

Sumber: Output Eviews 10 (2021, data diolah)

$$
F=\frac{\frac{(1657,291-1654,499)}{2}}{\frac{1654,499}{221}}=0,1865
$$

Selanjutnya, pada $\mathrm{X}_{2}$ diperoleh nilai $\mathrm{F}$ hitung sebesar 0,1566 dan $\mathrm{F}$ tabel 3,036710 atau $\mathrm{F}$ hitung $<\mathrm{F}$ tabel dengan $\mathrm{df}=2$ dan $\mathrm{n}=221$ serta signifikansi 0,05. Artinya, tidak terdapat perubahan hubungan antara perputaran piutang terhadap likuiditas selama pandemi covid-19.

$$
F=\frac{\frac{(1628,887-1621,589)}{2}}{\frac{1621,589}{221}}=0,1566
$$

Kemudian, pada $\mathrm{X}_{3}$ diperoleh nilai $\mathrm{F}$ hitung sebesar 0,8678 dan $\mathrm{F}$ tabel 3,036710 atau $\mathrm{F}$ hitung $<\mathrm{F}$ tabel dengan $\mathrm{df}=2$ dan $\mathrm{n}=221$ serta signifikansi 0,05. Artinya, tidak terdapat perubahan hubungan antara rasio hutang terhadap likuiditas selama pandemi covid-19.

$$
F=\frac{\frac{(1268,785-1258,848)}{2}}{\frac{1258,848}{221}}=0,8678
$$


Pada $\mathrm{X}_{4}$, diperoleh nilai $\mathrm{F}$ hitung sebesar 1,0366 dan $\mathrm{F}$ tabel 3,036710 atau $\mathrm{F}$ hitung < F tabel dengan $\mathrm{df}=2$ dan $\mathrm{n}=221$ serta signifikansi 0,05 . Artinya, tidak terdapat perubahan hubungan antara perputaran persediaan terhadap likuiditas selama pandemi covid-19.

$$
F=\frac{\frac{(1614,556-1599,551)}{2}}{\frac{1599,551}{221}}=1,0366
$$

Terakhir, pada $\mathrm{X}_{5}$ diperoleh nilai $\mathrm{F}$ hitung sebesar 0,0296 dan $\mathrm{F}$ tabel 3,036710 atau $\mathrm{F}$ hitung $<\mathrm{F}$ tabel dengan $\mathrm{df}=2$ dan $\mathrm{n}=221$ serta signifikansi 0,05. Artinya, tidak terdapat perubahan hubungan antara perputaran persediaan terhadap likuiditas selama pandemi covid19.

$$
F=\frac{\frac{(1645,489-1645,048)}{2}}{\frac{1645,048}{221}}=0,0296
$$

\section{Pengaruh ukuran perusahaan terhadap likuiditas}

Berdasarkan uji t statistik didapati hasil ukuran perusahaan tidak memiliki pengaruh terhadap likuiditas. Hasil tersebut tidak mendukung penjelasan pecking order theory terkait pemilihan sumber pendanaan manajemen perusahaan secara hierarki yang memiliki aset tinggi cenderung mengutamakan dana internal dan meminimalisir dana eksternal. Ukuran perusahaan ditinjau dari perolehan total kekayaan yang dimiliki perusahaan dan mencerminkan kinerjanya dalam memperoleh laba untuk mencapai titik kemandirian. Dapat dikatakan, para investor/kreditor tidak mempertimbangkan ukuran perusahaan untuk mengetahui kondisi likuiditas perusahaan karena ukuran perusahaan hanya menunjukkan perolehan aset dan terkait keputusan kebutuhan modal kerja tidak dipertimbangkan sehingga ukuran perusahaan tidak menjadi tolok ukur investor/kreditor dalam keputusan pendanaan yang berkaitan dengan likuiditas perusahaan.

Hasil penelitian didukung oleh Puspitasari \& Haryanto (2013) dan Sugiono \& Christiawan (2013) yang menyebutkan ukuran perusahaan tidak memiliki pengaruh signifikan terhadap likuiditas. Diperkuat oleh Puspitasari \& Haryanto (2013) semakin besar ukuran perusahaan tidak selalu meningkatkan kebutuhan modal kerja yang nantinya akan menghasilkan laba tambahan begitu juga sebaliknya, ukuran perusahaan yang kecil tidak selalu mencerminkan kebutuhan modal kerja yang sedikit dan menghasilkan laba yang kecil juga.

Hasil penelitian tersebut didukung oleh data perusahaan pada sektor consumer goods yaitu SCPI pada kuartal I tahun 2020 mengalami peningkatan total aset sebesar 0,2283 dan kebutuhan modal kerja yang dikeluarkan menurun serta likuiditas juga turut menurun sebesar 
6,1216. Selain itu, perusahaan pada sektor pertanian yaitu AALI pada kuartal II tahun 2020 mengalami penurunan total aset sebesar 0,0649 namun kebutuhan modal kerja yang dikeluarkan meningkat dan likuiditas meningkat sebesar 1,3367. Di sisi lain, perusahaan pada sektor consumer goods yaitu LMPI pada kuartal II tahun 2020 mengalami penurunan total aset sebesar 0,0275 dan kebutuhan modal kerja yang dikeluarkan menurun namun likuiditas yang diperoleh cenderung stagnan/perubahan yang tidak signifikan sehingga besar kecilnya ukuran perusahaan tidak memengaruhi likuiditas.

\section{Pengaruh perputaran piutang terhadap likuiditas}

Hasil penelitian menunjukkan bahwa perputaran piutang tidak memiliki pengaruh terhadap likuiditas. Hasil tersebut tidak mendukung penjelasan liquidity preference theory tentang perolehan pendapatan atas permintaan dapat diwujudkan dalam bentuk uang tunai atau kas. Perputaran piutang sebagai alat ukur tingkat efisiensi kualitas dari nilai modal yang ditanam dalam piutang sampai tertagih untuk dikonversikan kembali dalam kas. Para investor/kreditor tidak mempertimbangkan perputaran piutang untuk mengetahui kondisi likuiditas perusahaan.

Hasil penelitian didukung oleh Aminah \& Hidayat (2014), Gaol (2015) dan Maulana (2011) yang menjelaskan perputaran piutang tidak memiliki pengaruh signifikan terhadap likuiditas. Menurut Gaol (2015) dapat disebabkan adanya krisis global dan berdampak pada nilai piutang dengan penjualan yang menimbulkan kebutuhan akan kondisi darurat. Hal ini sesuai dengan kondisi pandemi covid-19 saat ini mengalami gangguan dan disrupsi rantai pasokan ekonomi yang berimbas pada perolehan pendapatan akibat pergeseran daya beli masyarakat. Selain itu, adanya penurunan volume penjualan yang disebabkan kebijakan pembatasan sosial berskala besar (PSBB) membuat masyarakat juga lebih prioritas dalam mengkonsumsi barang dan kegiatan ekspor-impor juga menurun sehingga nilai piutang terus meningkat sesuai periode berjalan dengan penjualan yang relatif stagnan/menurun.

Hasil penelitian tersebut didukung oleh data pada perusahaan sektor consumer goods yaitu AISA pada kuartal I tahun 2020 mengalami penurunan perputaran piutang sebesar 6,0021 disebabkan adanya penurunan volume penjualan diikuti dengan peningkatan nilai piutang. Namun, likuiditas yang diperoleh meningkat sebesar 0,7292. Selain itu, pada perusahaan sektor pertanian yaitu MGRO pada kuartal II tahun 2020 mengalami kenaikan perputaran piutang sebesar 20,6734 disebabkan adanya peningkatan volume penjualan dan nilai piutang. Namun, likuiditas yang diperoleh menurun sebesar 0,1107. Di sisi lain, pada perusahaan sektor pertanian yaitu MAGP pada kuartal I tahun 2020 mengalami penurunan perputaran piutang cukup signifikan sebesar 60,5902 disebabkan adanya penurunan volume penjualan diikuti 
dengan peningkatan nilai piutang. Namun, likuiditas yang diperoleh cenderung stagnan/perubahan yang tidak signifikan sehingga tinggi rendahnya perputaran piutang tidak memengaruhi likuiditas.

\section{Pengaruh rasio hutang terhadap likuiditas}

Analisis data menghasilkan rasio hutang memiliki pengaruh terhadap likuiditas. Hasil tersebut sesuai dengan pecking order theory pemilihan sumber pendanaan perusahaan secara hierarki. Rasio hutang sebagai gambaran nilai aset perusahaan yang didanai dengan dana eksternal. Hasil penelitian didukung oleh Misnawati (2019), Bem et al. (2014) dan Maulana (2011) jika rasio hutang memiliki pengaruh signifikan terhadap likuiditas. Hal tersebut mengindikasikan rasio hutang yang tinggi maka perusahaan secara hierarki lebih memilih pendanaan eksternal untuk mengontrol nilai aset perusahaan.

Konsisten dengan Husnan \& Pudjiastuti (2012) jika rasio hutang yang tinggi mengindikasikan bahwa perusahaan memilih pendanaan eksternal sebagai pendorong kegiatan operasional atau memang perusahaan lebih senang menggunakan dana eksternal meski dana internal mencukupi. Maka, hal tersebut menimbulkan beban tambahan selain nominal hutang seperti beban bunga sehingga adanya cost of external financing tinggi yang akan memengaruhi likuiditas perusahaan. Pernyataan tersebut diperkuat Bem et al. (2014) jika aset likuid tersebut digunakan untuk membayar hutang.

Hasil penelitian tersebut didukung oleh data pada perusahaan sektor pertanian yaitu UNSP pada kuartal I tahun 2020 mengalami peningkatan rasio hutang tertinggi sebesar 0,2121 dari kuartal sebelumnya dan diikuti dengan penurunan likuiditas sebesar 0,0122. Artinya, perusahaan tersebut menambah hutang untuk kegiatan operasionalnya agar tetap berkelanjutan dan terdapat beban tambahan yang harus dibayarkan dan tingkat likuiditasnya turut menurun. Di sisi lain, pada perusahaan sektor consumer goods yaitu DMND pada kuartal I tahun 2020 mengalami penurunan rasio utang sebesar 0,2236 dari kuartal sebelumnya dan diikuti dengan peningkatan likuiditas sebesar 2,5946 sehingga debt ratio memengaruhi likuiditas secara signifikan.

\section{Pengaruh perputaran persediaan terhadap likuiditas}

Berdasarkan hasil uji t statistik menunjukkan perputaran persediaan tidak memiliki pengaruh terhadap likuiditas. Hasil tersebut tidak mendukung penjelasan liquidity preference theory terkait perolehan pendapatan atas permintaan yang diwujudkan dalam bentuk uang tunai atau kas. Perputaran persediaan sebagai alat ukur tingkat efektivitas nilai persediaan barang yang tertanam untuk kemudian dengan segera didistribusikan agar memperoleh kas kembali. 
Para investor/kreditor tidak mempertimbangkan perputaran persediaan untuk mengetahui kondisi likuiditas perusahaan.

Hasil penelitian didukung Mulyanti \& Supriyani (2018) dan Gaol (2015) yang menyebutkan perputaran persediaan tidak memiliki pengaruh terhadap likuiditas. Hal tersebut terjadi karena adanya perbedaan jenis industri (Gaol, 2015). Perlakuan pengolahan antar barang baik input maupun output sesuai dengan periode lama waktu penyimpanan dan pemeliharaannya sehingga bergantung pada sifat dari barang tersebut dan hasil terbaik yang diperoleh akan menyesuaikan likuiditasnya.

Hasil penelitian tersebut didukung oleh data pada perusahaan sektor consumer goods yaitu ALTO. Pada kuartal II tahun 2020 perusahaan tersebut mengalami peningkatan perputaran persediaan sebesar 0,5133 disebabkan meningkatnya jumlah produksi dan penurunan persediaan. Dengan demikian, perusahaan berada di titik efektivitas tetapi likuiditas yang diperoleh menurun sebesar 0,0611. Selain itu, pada perusahaan sektor pertanian yaitu TBLA pada kuartal II tahun 2020 mengalami peningkatan perputaran persediaan sebesar 0,9119 disebabkan meningkatnya jumlah produksi dan persediaan. Perusahaan terindikasi adanya pengendapan dan likuiditas yang didapatkan menurun sebesar 0,1452. Di sisi lain, pada perusahaan sektor pertanian yaitu JAWA pada kuartal I tahun 2020 mengalami penurunan perputaran persediaan sebesar 6,2797 disebabkan meningkatnya jumlah produksi dan persediaan. Namun, likuiditas yang diperoleh cenderung stagnan/perubahan yang tidak signifikan sehingga tinggi rendahnya perputaran persediaan memengaruhi likuiditas.

\section{Pengaruh perputaran modal kerja terhadap likuiditas}

Analisis data menunjukkan perputaran modal kerja tidak memiliki pengaruh terhadap likuiditas. Dalam hal ini, tidak sesuai dengan signaling theory dimana investor/kreditor akan memberikan sinyal dalam keputusan berinvestasi. Perputaran modal kerja sebagai pengukur efektivitas modal kerja yang dimiliki untuk diinvestasikan dan akan kembali dalam bentuk kas. Perputaran modal kerja tidak menjadi pertimbangan khusus bagi investor/kreditor sebagai penilaian kondisi likuiditas perusahaan.

Hasil penelitian didukung Ammy \& Alpi (2018), Savitri (2014), Aji et al. (2016), Maulana (2011) dan Julita (2015) yang menyatakan jika perputaran modal kerja tidak memiliki pengaruh terhadap likuiditas. Menurut Kasmir (2012) hal ini dapat disebabkan tidak seimbangnya antar pos-pos aset lancar dan modal kerja siklusnya selalu berjalan atau berputar dan dapat ditinjau dari perputaran kas, perputaran piutang dan perputaran persediaan (Aji et al., 2016). Perputaran modal kerja yang tinggi belum tentu meningkatkan keefektifitasan 
investasinya dan begitu sebaliknya jika perputaran modal kerja yang dimiliki rendah tidak selalu mencerminkan investasinya tidak efektif dalam memperoleh laba tambahan.

Hasil penelitian tersebut juga didukung oleh data pada perusahaan sektor pertanian yaitu ANDI pada kuartal I tahun 2020 mengalami penurunan perputaran modal kerja sebesar 8,5477. Hal ini disebabkan adanya peningkatan modal kerja yang kemudian terjadi pengendapan dan likuiditas yang diperoleh menurun sebesar 0,0442. Selain itu, perusahaan pada sektor consumer goods yaitu DLTA pada kuartal II tahun 2020 mengalami peningkatan perputaran modal kerja sebesar 0,0434 disebabkan adanya penurunan modal kerja yang kemudian dikelola lalu diinvestasikan dan likuiditas yang diperoleh meningkat sebesar 2,4084. Disisi lain, pada perusahaan sektor consumer goods yaitu PANI pada kuartal II tahun 2020 mengalami peningkatan perputaran modal kerja sebesar 1,1393 disebabkan adanya penurunan modal kerja yang kemudian dikelola dan diinvestasikan. Namun, likuiditas yang diperoleh cenderung stagnan/perubahan yang tidak signifikan sehingga tinggi rendahnya perputaran modal kerja tidak memengaruhi likuiditas.

Perubahan hubungan ukuran perusahaan, perputaran piutang, rasio hutang, perputaran persediaan, dan perputaran modal kerja terhadap likuiditas selama pandemi covid-19

Berdasarkan hasil chow test menunjukkan tidak terdapat perubahan tiap variabel independen ukuran perusahaan, perputaran piutang, rasio hutang, perputaran persediaan, dan perputaran modal kerja terhadap likuiditas selama pandemi covid-19. Hal tersebut dapat disebabkan pada masa sebelum deklarasi covid-19 di Indonesia pada Q4 2019 belum memberikan tanda atau bukti kondisi pandemi yang masif dan peristiwa tersebut tidak termasuk adjusting events kinerja keuangan perusahaan beserta komponen-komponennya untuk kuartal berikutnya (CAS Unpad, 2020). Selain itu, setelah deklarasi covid-19 di Indonesia, kebijakan dan regulasi baru terkait penyesuaian kondisi pandemi untuk kegiatan perekonomian yang dibentuk belum memberikan balancing antar pihak-pihak terkait serta pemulihan yang cenderung melambat.

\section{E. KESIMPULAN}

Berdasarkan paparan di atas maka dapat disimpulkan bahwa hanya rasio hutang yang memiliki pengaruh terhadap likuiditas perusahaan sehingga menerima $\mathrm{H}_{3}$. Hal ini membuktikan selama pandemi covid-19 perusahaan cenderung melakukan pendanaan eksternal untuk kegiatan operasionalnya dan terindikasi adanya cost of external financing tinggi yang harus dipenuhi sehingga berdampak pada kondisi pengelolaan aset perusahaan dan perolehan kas untuk mencapai kondisi likuid. Hasil temuan pada penelitian tersebut diharapkan 
perusahaan dapat menjaga tingkat likuiditasnya dalam kondisi likuid dengan memperhatikan nilai rasio hutang. Hal ini dikarenakan tinggi rendahnya nilai aset perusahaan dengan hutang yang dimiliki dapat memengaruhi investor/kreditor dalam keputusan pendanaan maupun investasi. Selain itu, perusahaan juga turut mengelola nilai asetnya agar menghasilkan nilai tambahan untuk menekan pendanaan eksternal. Sedangkan ukuran perusahaan, perputaran piutang, perputaran persediaan, dan perputaran modal kerja tidak berpengaruh terhadap likuiditas. Selama pandemi covid-19 di Indonesia, tidak mengalami perubahan terkait hubungan variabel independen ukuran perusahaan, perputaran piutang, rasio hutang, perputaran persediaan, dan perputaran modal kerja terhadap likuiditas.

\section{Saran}

Bagi industri sektor pertanian dan consumer goods di masa pandemi covid-19 untuk meningkatkan evaluasi dan analisis kinerja serta strategi yang efektif khususnya di bidang keuangan terkait keputusan pendanaan eksternal yaitu rasio hutang agar kegiatan operasional perusahaan tetap sustainable dan mampu membangun trust terhadap pihak-pihak yang terlibat dalam keputusan investasi sehingga risiko illiquid dapat diminimalisasi. Untuk investor/kreditor perlu memperhatikan kebijakan dan regulasi agar nilai investasi yang telah ditanamkan memiliki prospek yang baik dan memberikan benefit. Selain itu, perlu mempertimbangkan pendanaan eksternal yang dilakukan oleh perusahaan karena tingkat rasio hutang yang tinggi memicu perusahaan untuk menjual asetnya apabila tidak mampu melunasi nominal serta beban bunga sehingga memengaruhi likuiditas. Agar maksimal, penelitian selanjutnya dapat menambahkan periode waktu pengamatan atau observasi dalam masa pandemi covid-19 agar data yang diperoleh lebih variatif mengikuti dinamika bisnis. Selain itu, dapat menggunakan sektor-sektor lainnya dan melibatkan variabel di luar model seperti pertumbuhan penjualan (Indarti \& Oetomo, 2019) dan profitabilitas (Bem et al., 2014).

\section{DAFTAR PUSTAKA}

Aji, P. P. W., Astuti, D. S. P., \& Widarno, B. (2016). Pengaruh Perputaran Piutang Dagang, Persediaan Dan Modal Kerja Terhadap Likuiditas Perusahaan CV Surya Mandiri Solo. Akuntansi dan Sistem Teknologi Informasi, 12(1), 27-35.

Allianz. (2020). Inilah Sektor Industri yang Bertahan di Tengah Pandemi COVID-19. Allianz Indonesia. Diakses dari https://www.allianz.co.id/explore/detail/inilah-sektor-industriyang-bertahan-di-tengah-pandemi-covid-19/105823

Aminah, S., \& Hidayat, L. (2014). Analisis Tingkat Pertumbuhan Penjualan dan Perputaran Piutang Terhadap Likuiditas Perusahaan. Symposium of Management, September 2014, $1-13$.

Ammy, B., \& Alpi, M. F. (2018). Pengaruh Perputaran Piutang dan Perputaran Modal Kerja 
Terhadap Likuiditas Perusahaan Otomotif dan Komponen. Jurnal Riset Finansial Bisnis, 2(3), 135-144.

Astuti, A.W., \& Maelona, R. (2013). Pengaruh Modal Kerja dan Perputaran Piutang Terhadap Likuiditas. Jurnal Akuntansi. 1-18

Badan Pusat Statistik. (2020). Produk Domestik Bruto (Lapangan Usaha). Diakses dari https://www.bps.go.id/subject/11/produk-domestik-bruto--lapangan-usaha.html\#subjekViewTab3

Bem, A., Prędkiewicz, K., Prędkiewicz, P., \& Ucieklak-Jeż, P. (2014). Determinants of Hospital's Financial Liquidity. Procedia Economics and Finance, 12(March), 27-36.

Brigham, E. F., \& Houston, J. F. (2014). Dasar-Dasar Manajemen Keuangan (10th ed.). Salemba Empat.

CAS Unpad. (2020). Dampak Pandemi Corona Terhadap Laporan Keuangan dan Praktik Bisnis di Indonesia. Fakultas Ekonomi Dan Bisnis Universitas Padjadjaran. Diakses dari https://feb.unpad.ac.id/dampak-pandemi-corona-terhadap-laporan-keuangan-danpraktik-bisnis-di-indonesia/

Chakiki, N. (2016). Pengaruh Perputaran Piutang dan Perputaran Modal Kerja Terhadap Likuiditas Perusahaan Consumer Goods. Jurnal Ilmu Dan Riset Manajemen, 5(9). 1-15

Dewi, R. (2016). Pengaruh Perputaran Total Aset, Perputaran Modal Kerja, Perputaran Piutang dan Perputaran Persediaan Terhadap Likuiditas Pada Perusahaan Makanan dan Minuman Yang Terdaftar Di BEI Periode Tahun 2011 - 2014. Jurnal Umrah, 1-25.

Fahmi, I. (2011). Analisa Laporan Keuangan. Bandung: Alfabeta.

Gaol, R. L. (2015). Pengaruh Perputaran Persediaan, Perputaran Piutang dan Pertumbuhan Penjualan Terhadap Likuiditas pada Perusahaan Industri Barang Konsumsi yang Terdaftar di Bursa Efek Indonesia. Akuntansi, 1(2), 181-202.

Gill, A., \& Mathur, N. (2011). Factors that Influence Corporate Liquidity Holdings in Canada. Journal of Applied Finance \& Banking, 1(2), 133-153.

Hamdi, A. (2014). Pengaruh Perputaran Modal dan Likuiditas Terhadap Profitabilitas dan Harga Saham. Manajemen Bisnis, 3(1), 1-13.

Hani, S. (2015). Teknik Analisa Laporan Keuangan. Jakarta: In Media.

Harjito, A., \& Martono. (2008). Manajemen Keuangan (1st ed.). Yogyakarta: EKONISIA.

Heriyanto, S., \& Herliana, T. (2016). Pengaruh Perputaran Modal Kerja Terhadap Tingkat Likuiditas Perusahaan Manufaktur Tahun 2011 - 2013. Ekonomia, 5(2), 68-78.

Husnan, S., \& Pudjiastuti, E. (2012). Dasar-Dasar Manajemen Keuangan (6th ed.). Yogyakarta: UPP STIM YPKN.

Indarti, P. R., \& Oetomo, H. W. (2019). Pengaruh Arus Kas, Perputaran Piutang, Perputaran Modal Kerja dan Pertumbuhan Penjualan Terhadap Likuiditas. Jurnal Ilmu Dan Riset Manajemenm, 8(1), 1-18.

Jogiyanto, H. M. (2000). Teori Portofolio dan Analisis Investasi. Yogyakarta: BPFE UGM. Julita. J. (2015). Pengaruh Perputaran Modal Kerja dan Perputaran Kas Terhadap Likuiditas Pada Perusahaan Pertambangan yang Terdaftar Di Bursa Efek Indonesia. Kumpulan 
Jurnal Dosen UMSU, 9(2), 1-9.

Kasmir. (2012). Analisis Laporan Keuangan. Jakarta: PT. Rajagrafindo Persada.

Kasmir. (2015). Analisis Laporan Keuangan (Pertama). Jakarta: Rajawali Pers.

Kementrian Pertanian Republik Indonesia. (2020). Sektor Pertanian Penyelamat

Pembangunan Nasional di Masa Covid. 02 November 2020. Diakses dari

https://www.pertanian.go.id/home/?show=news\&act=view\&id=4557

Keown, A. J., Martin, J. D., Petty, J. W., \& Scott, D. F. (2008). Manajemen Keuangan:

Prinsip dan Penerapan Edisi ke 10 Jilid 1. Jakarta: PT. Indeks.

Keynes, J. M. (1936). The General Theory of Employment, Interest and Money. Brace and World.

Kim, C.-S., Mauer, D. C., \& Sherman, A. E. (1998). The Determinants of Corporate Liquidity: Theory and Evidence. The Journal of Financial and Quantitative Analysis, 33(3), 335-359.

Maulana, R. A. (2011). Pengaruh Perputaran Piutang, Perputaran Modal Kerja, Dan Rasio Utang Terhadap Likuiditas pada Perusahaan Pertambangan yang Terdaftar di Bursa Efek Indonesia. Academia.Edu. Diakses dari https://www.academia.edu/27661817/Pengaruh_Perputaran_Piutang_Perputaran_Modal _Kerja_dan_Rasio_Utang_terhadap_Likuiditas

Misnawati. (2019). Analisa Faktor Yang Mempengaruhi LikuiditaspPada Industri Ritel Yang Terdaftar pada Bursa Efek Indonesia Tahun 2010-2017. Akrab Juara, 4(3), 130-142.

Moeljadi. (2006). Manajemen Keuangan Pendekatan Kuantitatif dan Kualitatif. Yogyakarta: BPFE.

Mulyanti, D., \& Supriyani, R. L. (2018). Pengaruh Perputaran Kas dan Perputaran Persediaan Terhadap Likuiditas pada PT Ultra Jaya, Tbk. Jurnal Kajian Ilmiah, 18(1), 34-42.

Munawir, S. (2007). Analisa Laporan Keuangan (4th ed.). Yogyakarta: Liberty.

Munawir, S. (2010). Analisa Laporan Keuangan.Yogyakarta: Liberty.

Myers, S. C. (1984). The Capital Structure Puzzle. The Journal of Finance, 39(3), 574-592.

Ningsih, R. F., \& Soekotjo, H. (2018). Pengaruh Perputaran Kas Perputaran Modal Kerja dan Perputaran Piutang Terhadap Likuiditas pada Perusahaan Pulp and Paper. Jurnal Ilmu dan Riset Manajemen, 1-17.

Norvaišienè, R., \& Stankevičienè, J. (2014). Impact of Companies’ Internal Factors on Stock Liquidity in Baltic Markets. Procedia-Social and Behavioral Sciences, 156(April), 543-547.

Pranaditya, A. (2018). Pengaruh Perputaran Modal Kerja Dan Perputaran Persediaan Terhadap Likuiditas di Medias Net Profit Margin (Studi Kasus Pada PT. "CFU" Semarang Periode 2013-2017). Jurnal Ekonomi Dan Bisnis Kontemporer, 2(2).

Prihadi, T. (2010). Analisis Laporan Keuangan. PPM Manajemen.

Puspitasari, A. V., \& Haryanto, A. M. (2013). Analisis Pengaruh Profitabilitas, Ukuran Perusahaan, Perputaran Piutang, Rasio Hutang, Dan Operating Cycle Terhadap Likuiditas (Studi Kasus Pada Perusahaan Makanan Dan Minuman Yang Terdaftar Di 
BEI Periode 2007 -2010). Diponegoro Journal Management, 2(2), 66-77.

Ridhoi, M. A. (2020). Industri-industri Potensial di Tengah Kontraksi Ekonomi.

Katadata.Co.Id. Diakses dari:

https://katadata.co.id/muhammadridhoi/indepth/5f2ca2767ab84/industri-industripotensial-di-tengah-kontraksi-ekonomi

Rudianto. (2009). Pengantar Akuntansi: Konsep dan Teknik Penyusunan Laporan Keuangan. Jakarta: Erlangga.

Saputra, I., Indrawan, A., \& Sudarma, A. (2020). Pengaruh perputaran modal kerja terhadap likuiditas perusahaan jasa sub sektor property, real estate dan kontruksi bangunan. BUDGETING : Journal of Business, 1(2), 136-146.

Savitri, D.A.M. (2014). Analisis Pengaruh Working Capital Turnover Terhadap Likuiditas Dan Profitabilitas. Jurnal Ilmu Manajemen Dan Akuntansi Terapan, 5(1), 48-55.

Savitri, D.A.M., \& Dianingsih, H. I. (2015). Analisis Perbandingan Faktor-Faktor Yang Mempengaruhi Likuiditas Pada Industri Pertanian, Kehutanan Dan Perikanan, Dan Industri Otomotif. Jurnal Ilmu Manajemen Dan Akuntansi Terapan, 6(2), 17-33.

Sawir, A. (2004). Kebijakan Pendanaan dan Restrukturisasi Perusahaan. Jakarta: PT. Gramedia Pustaka Utama.

Seftianne, \& Handayani, R. (2011). Faktor-Faktor Yang Mempengaruhi Struktur Modal Pada Perusahaan Publik Sektor Manufaktur. Jurnal Bisnis Dan Akuntansi, 13(1), 39-56.

Seligova, M. (2017). Corporate Liquidity And Financial Indicators In [ Likvidita podniků a finanční ukazatel e ve vybraných odvětvích v České republice ]. Acta Academica Karviniensia, 17(4), 87-99.

Sudana, I.M. (2011). Manajemen Keuangan Perusahaan. Erlangga.

Sugiono, L.P., \& Christiawan, Y. J. (2013). Analisa Faktor yang Mempengaruhi Likuiditas Pada Industri Ritel yang Terdaftar Pada Bursa Efek Indonesia Tahun 2007-2012. Business Accounting Review, 1(2), 298-305.

Sunyoto. (2013). Analisis Laporan Keuangan untuk Bisnis. Yogyakarta: CAPS

Yunita, R., \& Argamaya. (2017). Analisis Faktor - Faktor yang Mempengaruhi Nilai Current Ratio pada PT Tiga Pilar Sejahtera Food, Tbk Periode 2010-2015. Media Riset Akuntansi, 7(1). 1-21. 